\title{
APATITE AS A PHOSPHORUS FERTILIZER
}

\author{
MartTi Salonen \\ Agricultural Research Centre, Department of Agricultural Chemistry and Physics, Tikkurila
}

Received September 16, 1968

When the investigations into the possibilities of utilizing the apatite deposit, found in the parish of Siilinjärvi, Finland (SALONEN et al., 1966), were started, an experiment with finely ground, chemically untreated apatite concentrate was included in the pot tests. The tests were first carried out in acid mineral soil ( $\mathrm{pH} 4.9$ ), that was extremely poor in phosphorus. Oats were used as test plants and the experiment was continued for three years. No indication of a phosphorus effect could, however, be observed. Already in 1935 similar results had been obtained at our department when the influence of Kola apatite on an acid mineral soil ( $\mathrm{pH} 4.3$, TERÄsvUORI, unpublished manuscript) was studied. Comparable results have been noted in investigations abroad. HuIKARI (1964, p. 16), however, presents positive results for forest fertilizations with apatite on bog peat soils. For this reason it was decided to carry out another studies into the phosphate fertilizing effect of apatite on bog peat. At the same time the ability of pine and oats to utilize the not easily soluble phosphorus of apatite was compared.

\section{Pot tests with apatite}

Th e a pat it e con c e n t r a t e used in the tests was delivered by Lohjan Kalkkitehdas $\mathrm{Oy}$, which had prepared it from the Siilinjärvi apatite. The material was very finely ground, having passed through a sieve with $0.06-\mathrm{mm}$ holes. According to analyses the concentrate contained:

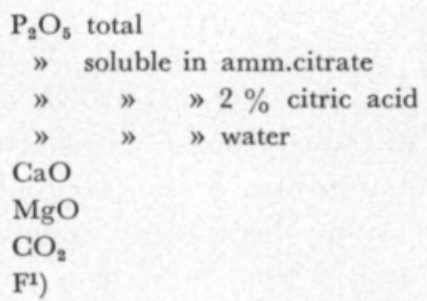
$21.00 \%$
$0.17 \%$
0.14
traces only
$49.70 \%$
$1.83 »$
$21.40 "$
1.10 ”

1) Made at the Research Laboratory of Rikkihappo Oy under the supervision of Dr. T. VAHERVUORI. 
The material was half apatite and half limestone and contained a small amount of dolomite. The fluorine content was smaller than in the well-known Kola apatite, which the Siilinjärvi apatite resembles in many respects, judging by the X-ray diffraction dia$\left.\operatorname{grams}^{1}\right)$.

The soil used in the test was Sphagnum fuscum peat, obtained from a natural peatland area at the Leteensuo Experimental Station. The $\mathrm{pH}$ of the peat was 3.9 and it was extremely poor in exchangeable calcium and plant nutrients. In the autumn it was shredded fine and carefully mixed while still moist. Over the winter the soil was kept in a cool place and in the spring it was put in the test pots (enamelled Mitscherlich pots) after application of fertilizers and other compounds. In this way it was possible to mix the components homogeneously into the peat. The volume of the soil in each pot was 4.51 .

$\mathrm{Tr}$ e a t m e n t s. The experimental treatments were the same irrespective of the test plant and sowing time. All pots were filled at the same time and kept under similar moisture and temperature conditions.

The following basic fertilization was applied to all pots:

$\begin{array}{lc}\text { ammonium nitrate } & 2.858 \mathrm{~g} / \mathrm{pot} \\ \text { potassium sulphate } & 0.925 \mathrm{~m} \\ \text { magnesium sulphate } & 2.000 \mathrm{\prime \prime} \\ \text { trace element mixture }(\mathrm{Cu}, \mathrm{B}, \mathrm{Mn}, \mathrm{Mo}) & 10 \mathrm{ml} \\ \text { ferri-EDTA } & 15 \mathrm{mg} / \mathrm{pot}\end{array}$

The amount of potassium in particular was small for the oats, whereas for the pine it was adequate, at least in the beginning. Too much potassium could have been harmful to the pine, especially during its early stages of development.

Experimental treatments:

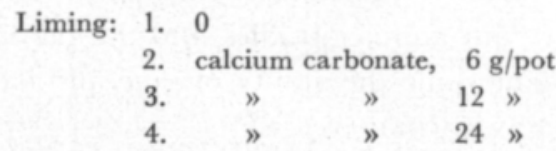

Phosphorus application:
1. 0
2. superphosphate (sf) $\quad 5.128 \mathrm{~g} /$ pot $=1000 \mathrm{mg} \mathrm{P}_{2} \mathrm{O}_{5}$
3. apatite concentrate (ap) $4.760 "=1000$ "

All treatments were not included each year. The various treatments in the respective years are presented in Tables 1 and 2.

\section{Sowing, attendance and harvest of test plants}

$\mathrm{P}$ in e (Pinus silvestris, Scotch pine) was sown from seeds collected in November 1965 from pines at Tikkurila. Because the initial growth of pine seedlings is always slow and because we had only one growing season at our disposal, we extended this period by first keeping the pots in a greenhouse. On March 9, 1966, 40 seeds of pine per pot were sown.

1) Made at the Research Laboratory of Rikkihappo Oy under the supervision of Dr. T. VAHERvUORI. 
Emergence was satisfactory in the limed as well as in the unlimed pots fertilized with apatite. At the beginning of June the pots were moved outdoors into a wire net cage.

In the warmth of the greenhouse and with an abundance of plant nutrients, the growth was rapid with the exception of the pots without liming and without apatite. Moving the pots outdoors did not seem to disturb the growth, which continued at the same rate until the harvest in early September. At the time of the harvest the height of the tallest plants was $28 \mathrm{~cm}$ and they were $6 \mathrm{~mm}$ in diameter. Many plants were branched. The harvest took place September 8-12, 1966. The stems were cut at soil surface. After drying it was easy to separate stems and needles. The pine roots were also harvested. The separation of the roots from the peat soil was relatively easy. It may be mentioned that the pine roots were covered with mycorrhiza, although no inoculation had been performed.

$\mathrm{O}$ a t s (variety Pendek) were used as trial plants side by side with pine in 1966. Because no unlimed treatments were included for coats in 1966, and these later proved to be indispensable, the pot tests with oats were repeated in 1967. The repeated tests were carried

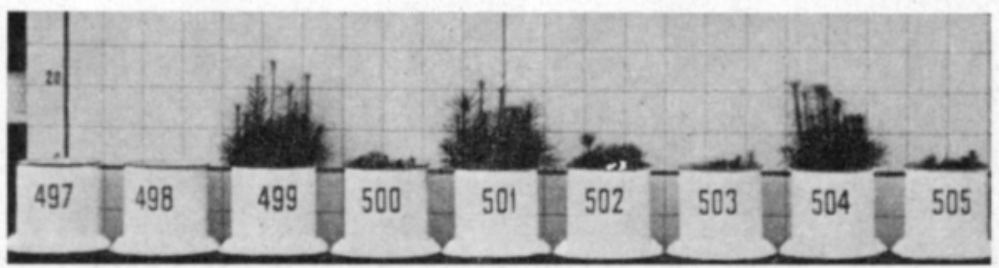

Fig. 1. Test pots $8 / 8-66$, pine. Treatments and numbers of test pots:

\begin{tabular}{ccccc} 
& \multicolumn{3}{c}{ phosphorus" fertilization } \\
liming: $\quad 0$ & 0 & sf & ap \\
$\Rightarrow$ & 12 g/pot & 497 & 498 & 499 \\
$\Rightarrow$ & $24 \Rightarrow$ & 500 & 501 & 502 \\
& & 503 & 504 & 505
\end{tabular}

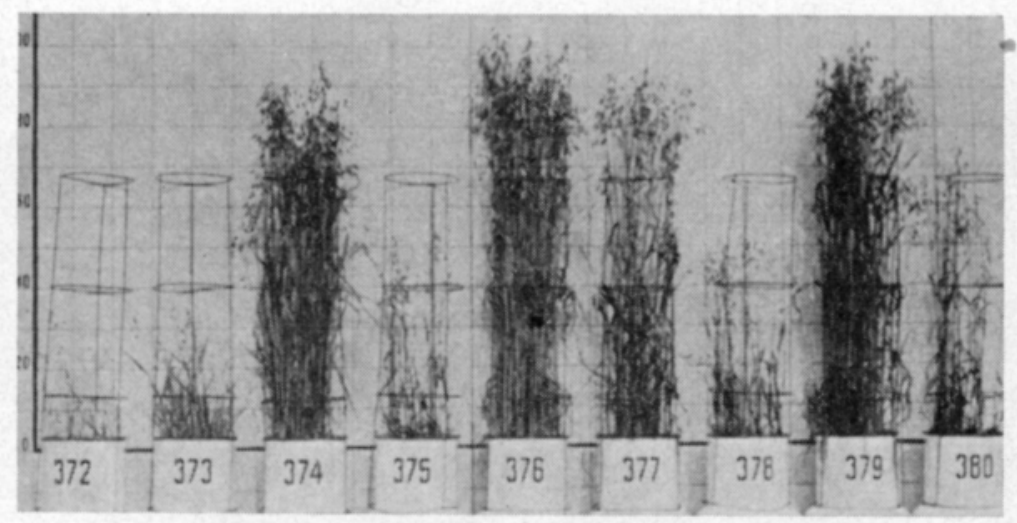

Fig. 2. Test pots 17/8-67, oats. Treatments and numbers of test pots:

\begin{tabular}{clccc} 
& & \multicolumn{3}{c}{ phosphorus fertilization } \\
liming: & 0 & 0 & sf & ap \\
$\#$ & 6 g/pot & 372 & 373 & 374 \\
$\Rightarrow$ & $12 \quad \#$ & 375 & 376 & 377 \\
& & 378 & 379 & 380
\end{tabular}




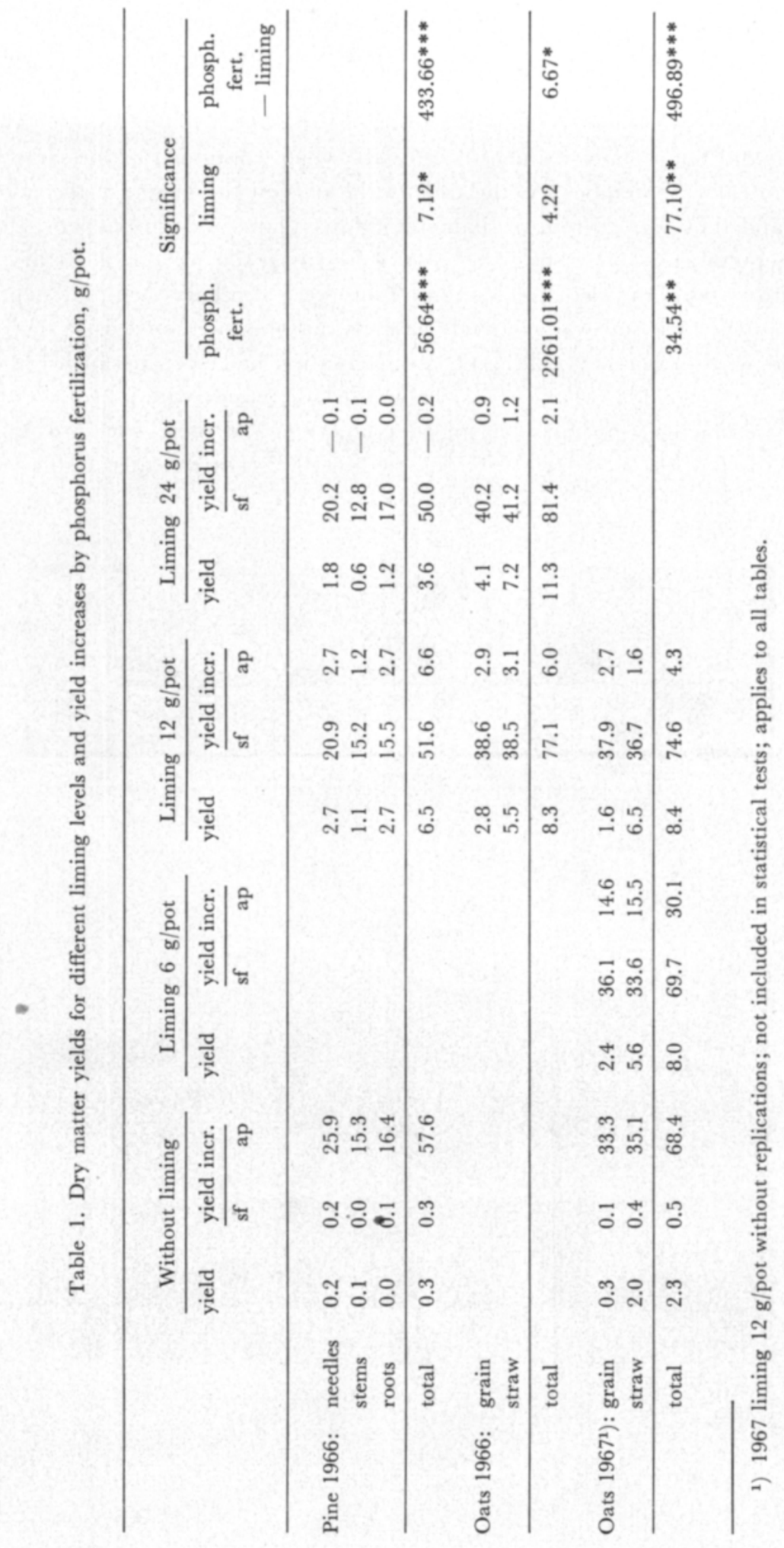


out using the same bog peat soil and the same techniques as in 1966. The pots were packed in March and kept in a greenhouse, but the oats were sown at the end of May in both years.

The oats grew fairly well in pots with liming and phosphate fertilization and in unlimed pots with apatite fertilization. In the pots showing the best growth, brown stains typical of potassium deficiency were noted in the glumes of the oats when ripening time approached.

The oats were harvested when the normally grown plants were ripe. Grain and straw yields, expressed as dry matter $\mathrm{g} / \mathrm{pot}$, are given in Table 1.

It should be mentioned that in both years $1-2$ weeks after the treatments plenty of green algae was observed on the surface of the peat soil in all pots which had received phosphorus fertilization, superphosphate or apatite.

\section{Presentation of experimental yields}

In order to facilitate the interpretation of the test results, the yields of pine and oats are presented together in Table 1. The results for the oats are for two growing seasons, but - as can be seen - the same treatments have given the same results in both years (liming $12 \mathrm{~g} /$ pot in 1967 without replications).

Table 1 shows that the apatite concentrate has been an effective phosphorus fertilizer for pine as well as for oats in unlimed Sphagnum fuscum peat, which was so acid that when

Table 2. Plant nutrient contents of experimental yields, mg/pot.

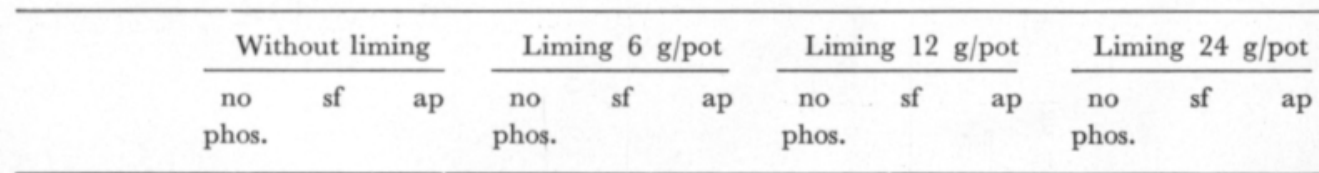

Pine 1966:

$\begin{array}{lrrr}\mathrm{N} & \text { n.d. } & \text { n.d. } & \\ \mathrm{P}_{2} \mathrm{O}_{5} & 1 & 5 & 856 \\ \mathrm{~K}_{2} \mathrm{O} & 2 & 7 & 500 \\ \mathrm{CaO} & 1 & 2 & 199 \\ \mathrm{MgO} & 1 & 2 & 131\end{array}$

$\begin{array}{rrrrrr}208 & 867 & 317 & 99 & 698 & 92 \\ 12 & 336 & 24 & 7 & 252 & 6 \\ 69 & 512 & 160 & 61 & 484 & 58 \\ 44 & 387 & 102 & 51 & 462 & 52 \\ 16 & 123 & 32 & 11 & 118 & 10\end{array}$

Oats 1966:

$\mathrm{N}$

$\mathrm{P}_{2} \mathrm{O}_{5}$

$\mathrm{K}_{2} \mathrm{O}$

$\mathrm{CaO}$

$\mathrm{MgO}$

$\begin{array}{rrrrrr}221 & 934 & 340 & 228 & 1197 & 259 \\ 13 & 696 & 24 & 15 & 402 & 20 \\ 162 & 514 & 278 & 221 & 520 & 234 \\ 33 & 480 & 55 & 56 & 410 & 71 \\ 17 & 224 & 29 & 26 & 228 & 32\end{array}$

Oats 1967:

$\begin{array}{lrrrrrrrrr}\mathrm{N} & 46 & 95 & 747 & 195 & 762 & 694 & 223 & 870 & 232 \\ \mathrm{P}_{2} \mathrm{O}_{5} & 5 & 53 & 450 & 12 & 633 & 98 & 13 & 657 & 23 \\ \mathrm{~K}_{2} \mathrm{O} & 20 & 49 & 436 & 110 & 438 & 382 & 153 & 516 & 211 \\ \mathrm{CaO} & 3 & 2 & 95 & 19 & 289 & 107 & 32 & 402 & 44 \\ \mathrm{MgO} & 4 & 15 & 136 & 15 & 169 & 94 & 21 & 215 & 26\end{array}$

1) n.d. = not determined. 


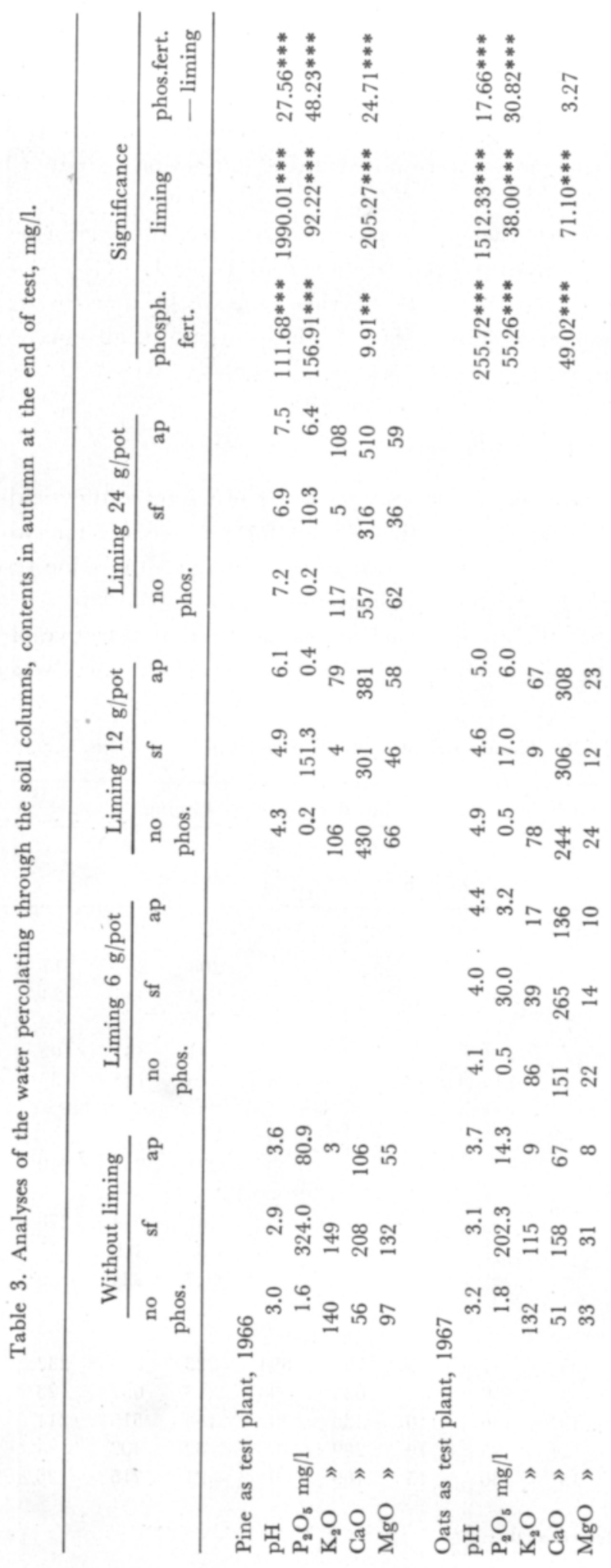


superphosphate was used as a fertilizer no noticeable growth could be recorded. Even a scant application of lime, $6 \mathrm{~g} / \mathrm{pot}$, received only by the oats in these tests, has made the superphosphate usable and caused a very marked decrease in the effect of apatite. Adequate liming has completely counteracted the effect of apatite.

The quantities of the plant nutrients are given in Table 2 as sums of the nutrients in the yields. It is apparent that the phosphorus of the apatite really appears in the plants in cases where apatite fertilization has increased the dry matter yield. The two treatments, apatite without liming and superphosphate with liming, show no pronounced difference in the amounts of phosphorus. In cases where the growth has been best, the amount of potassium in the yields has equalled the amount originally supplied by fertilization. As the Sphagnum fuscum peat contains practically no potassium there has been a severe deficiency of potassium at the end of the growing period.

Examining the total amounts of plant nutrients in the yields one can furthermore observe that they have been about the same for both the experimental plant species, despite their utter dissimilarity. The most important difference is the amount of phosphorus which the oats have taken up in much greater quantities in relation to other plant nutrients than the pine.

\section{The plant nutrient contents of water percolating through the soil of the experimental pots}

In the Mitscherlich method used in the tests, the pots were kept outdoors. It was therefore impossible to exclude precipitation. At the time of the harvest there was water in the base-dishes. In 1966 the largest quantity was $700 \mathrm{ml}$ and in 1967 it was $2500 \mathrm{ml}$. Each basedish was made to contain the same amount of water by using the above mentioned quantities and pouring water into the soil of the pots lacking in this respect. The percolated water in each pot was then analysed, and the results are given in Table 3.

In particular one must point out the phosphorus contents of the percolated water. When unlimed bog peat was treated with superphosphate the contents were very high. Liming has markedly decreased the phosphorus content of the water. The apatite concentrate has under no circumstances noticeably raised the phosphorus content of the percolated water. In pots showing good growth, the potassium content of the percolated water has in fact been very low.

\section{Analyses of the soils in the pots after the harvest}

After the harvest $\mathrm{pH}$ determinations in water suspension as well as in $1 \mathcal{N ~ K C l}$-solution were made from the soils in the test pots. The results of these determinations as well as those of the soil analyses made according to the ammonium acetate method (Vuorinen and MÄкrTIE 1955; KURKI et al., 1965) are presented in Table 4. As can be seen there are differences in the test results for the different years regardless of the fact that the amount of soil and the treatments were the same in both years. The use of another test plant and the different amounts of water in the base-dishes have influenced the results.

From the $\mathrm{pH}$ figures it appears that the apatite concentrate, on account of its carbonate content, has somewhat decreased the acidity and increased the content of exchangeable calcium in the soil. In this connection the phosphorus figures are the most interesting ones. For the Sphagnum fuscum peat, which is extremely deficient in phosphorus, even without 


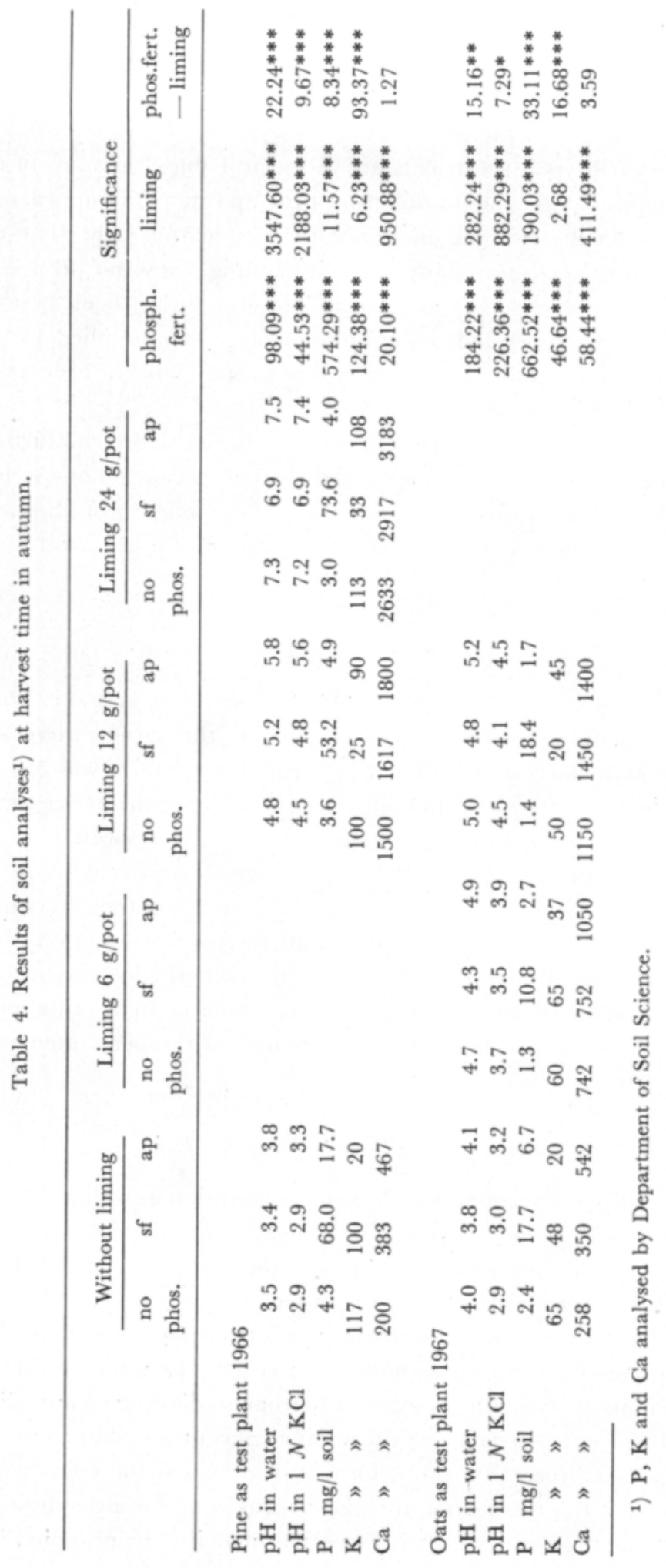


any phosphorus fertilization, moderate phosphorus numbers have been obtained. This phenomenon, which has been known for a long time, is obviously due to the fact that pure bog peat contains no phosphorus fixing substances, and thus even traces of phosphorus can be disclosed in the analysis. For the same reason apatite has apparently somewhat raised the phosphorus figures, especially in peat without liming. Superphosphate has raised the phosphorus figures considerably and by approximately the same amount in limed and unlimed peat.

\section{Discussion}

Many research workers in various countries have studied the phosphorus effect of chemically untreated finely ground apatite, although the results have generally been negative, e.g. Frank (1943), Lundblad (1957) and Döring (1958). Ansorge (1966), using lupine as a test plant, obtained a slight phosphorus effect for Kola apatite. MunK (1960) studied the influence of the grade of fineness and reached the conclusion that Kola apatite may exert a phosphorus effect if the particles are less than $0.002 \mathrm{~mm}$ in diameter. HöWELER and WoodrufF (1968) obtained similar results.

The majority of the studies on the phosphorus effect of apatite have been made using acid mineral soil. Under such circumstances we did not observe any effect either. Beside being very acid, the culture medium apparently must not contain any phosphorus fixing constituents. Pure Sphagnum fuscum peat satisfies these requirements.

As test plants we used pine ánd oats. Even though these two plant species are very dissimilar, there seems to be no major difference between them with regard to the uptake of phosphorus from superphosphate on the one hand and from apatite on the other. It is, however, possible that the solubility of the phosphate of apatite and the availability of it for plants conclusively depends on the qualities of the culture medium. Thus the only requirement is that the plants endure these extreme conditions.

Although apatite, under certain conditions, may be a useful phosphorus fertilizer for oats, it cannot be considered important in practical agriculture. On the other hand it is possible that in forest fertilization, on bog peat soils, it could be utilized. Apparently the calcium (magnesium) carbonate, included as an impurity, is also beneficial. Its proportion could probably be even greater than in the concentrate used in the present tests. It can be anticipated that fertilization of large bog peat areas with easily soluble phosphates, on account of the water percolating through the peat, may cause harmful effects in water systems. With the use of not readily soluble phosphates this risk is considerably diminished.

\section{$S u m m$ ary}

In pot trials, where very acid Sphagnum fuscum peat has been used as a growth substance, a finely ground but chemically untreated apatite concentrate has given a noticeable phosphorus effect for pine as well as for oats. Even a scarce liming has significantly diminished the phosphorus effect and a satisfactory liming has altogether stopped it.

Apatite may be a suitable phosphorus fertilizer in forest manuring on bog peat soils. The carbonate included as an impurity in apatite may also be beneficial. By the use of not 
readily soluble phosphorus fertilizers one may diminish the possibilities of phosphorus entering water systems; this should be taken into consideration when the areas to be fertilized are very large.

\title{
LITERATURE
}

Ansorge, H. 1966. Untersuchungen über die Phosphorsäureaufnahme aus Kola-Apatit und »Hyperphos» durch Lupinen und Hafer. Albrecht-Thaer-Archiv 10: 153-166.

DörIng, H. 1958. Untersuchungen über die bessere Düngewirkung des weicherdigen Rohphosphates Hyperphos im Vergleich zum kristallinen Kola-Apatit. Z. PflErnähr. Düng. 83: 140-148.

FRANK, O. 1943. Jämförande gödslings- och kalkningsförsök med apatithaltig dolomitisk kalksten från Alnön. Lantbrukshögskolan, Jordbr.förs.anst., Medd. Nr 8.

HUtKari, O. 1964. Erilaisten fosfori- ja typpilannoitteiden soveltuvuudesta ojitettujen suometsien lannoitukseen. Leipä leveämmäksi 12/1: 13-17.

HöWeler, R. H. and Woodruff, C. M. 1968. Dissolution and availability to plants of rock phosphates of igneous and sedimentary origin. Soil Sci. Soc. Amer. Proc. 32: 79-82.

Kurki, M., Lakanen, E., Mäkitie, O., Sillanpä̈̈, M. and Vuorinen, J. 1965. Viljavuusanalyysien tulosten ilmoitustapa ja tulkinta. Summary: Interpretation of soil testing results. Ann. Agric. Fenn. 4: 145-153.

LuNDBLAD, K. 1957. Om råfosfater och jämförande försök med sådana fosforgödselmedel på myrjord. Stat. Jordbr. förs. Medd. $\mathrm{Nr} 80$.

MUnK, H. 1960. Über $\mathrm{P}_{2} \mathrm{O}_{5}$-Wirksamkeit und Teilchengrösse bei Apatiten. Landw. Forsch. 13: 296-302. SALONEN, M., TAINIO, A. and TÄHTINEN, H. 1966. Kalsiumkarbonaattipitoisesta apatiitista valmistettujen emäksisten fosforilannoitteiden käyttöarvoa koskevia tutkimuksia. Summary: Studies on the value of alkaline phosphate fertilizers prepared from calcite-containing apatite. Ann. Agric. Fenn. 5:1225.

Vuorinen, J. and MÄкrтIE, O. 1955. The method of soil testing in use in Finland. Agrogeol. julk. 63.

\section{SELOSTUS}

\section{APATIITTI FOSFORILANNOITTEENA}

\author{
MARTti Salonen
}

Maatalouden tutkimuskeskus, maanviljelyskemian ja -fysiikan laitos, Tikkurila

Tutkittaessa Siilinjärveltä löydetyn apatiitin käyttömahdollisuuksia on astiakokeissa ollut mukana myös hienoksi jauhettu, mutta kemiallisesti käsittelemätön apatiittirikaste.

Happamalla ja suuresti fosforilannoituksen tarpeessa olevalla kivennäismaalla se ei antanut mitään fosforivaikutusta kauralla enempää kuin männylläkään. Tulos on yhdenmukainen useimpien aikaisempien tutkimustulosten kanssa.

Pelkällä raa'alla rahkaturpeella (Sphagnum fuscum) sensijaan sekä kaura että mänty saivat apatiitista runsaasti fosforia. Jos kuitenkin rahkaturve kalkittiin sopivaksi katsottavalla määrällä, apatiitin teho loppui (taul. 1 ja 2). Kokeissa olleiden kasvilajien välillä ei ollut eroa apatiitin fosforin käytössä niin kaikin puolin erilaisia kasveja kuin kaura ja mänty ovatkin. Apatiitin fosforin käyttökelpoisuus on ratkaisevasti riippunut kasvualustan ominaisuuksista. Maan pitää ilmeisesti olla paitsi hapan myös vapaa fosfaattia pidättävistä aineista. Pelkkä rahkaturve vastaa näitä vaatimuksia.

Kun pelkälle rahkaturpeelle fosfori on annettu veteen liukenevana superfosfaattina, on maan läpi valuneen veden fosforipitoisuus ollut paljon korkeampi kuin annettaessa vaikeasti liukenevaa apatiittia (taul. 3). Tämä seikka on hyvä tietää lannoitettaessa suuria rahkasuoalueita ja pyrittäessä välttämään fosforin joutumista vesistöihin.

Maa-analyysin tulokset (taul. 4) osoittavat, että käytetyllä apatiittirikasteella on ollut selvän maan happamuutta vähentävä ja vaihtuvaa kalkkia lisäävä vaikutus, mikä johtuu șen sisältämästä kalsiumkarbonaatista. 